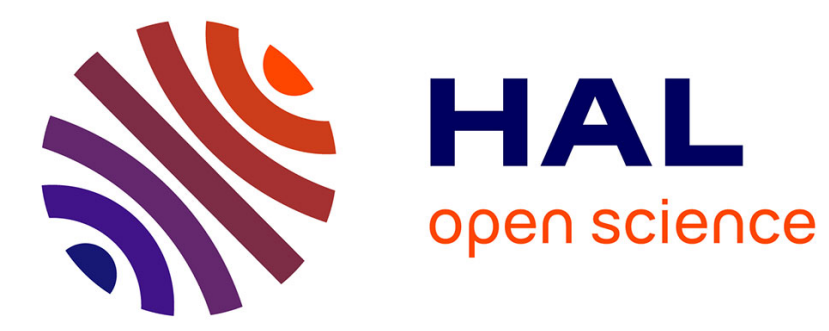

\title{
Pathophysiological aspects of the thick ascending limb and novel genetic defects: HELIX syndrome and transient antenatal Bartter syndrome
}

Rosa Vargas-Poussou

\section{- To cite this version:}

Rosa Vargas-Poussou. Pathophysiological aspects of the thick ascending limb and novel genetic defects: HELIX syndrome and transient antenatal Bartter syndrome. Pediatric Nephrology, 2021, 10.1007/s00467-021-05019-6 . hal-03263462

\section{HAL Id: hal-03263462 \\ https: / hal.sorbonne-universite.fr/hal-03263462}

Submitted on 17 Jun 2021

HAL is a multi-disciplinary open access archive for the deposit and dissemination of scientific research documents, whether they are published or not. The documents may come from teaching and research institutions in France or abroad, or from public or private research centers.
L'archive ouverte pluridisciplinaire $\mathbf{H A L}$, est destinée au dépôt et à la diffusion de documents scientifiques de niveau recherche, publiés ou non, émanant des établissements d'enseignement et de recherche français ou étrangers, des laboratoires publics ou privés. 


\section{Pathophysiological aspects of the thick ascending limb and novel genetic}

defects: HELIX syndrome and transient antenatal Bartter syndrome

Rosa Vargas-Poussou ${ }^{1,2,3}$

${ }^{1}$ Assistance Publique Hôpitaux de Paris, Hôpital Européen Georges-Pompidou, Department of Genetics, Paris, France.

${ }^{2}$ Centre de Référence des Maladies Rénales Héréditaires de l'Enfant et de l'Adulte (MARHEA), Paris, France

${ }^{3}$ Centre de Recherche des Cordeliers, INSERM, Sorbonne Université, Université de Paris, Paris, France

Corresponding author:

Rosa Vargas-Poussou

Hôpital Européen Georges-Pompidou,

Department of molecular genetics,

20-40 rue Leblanc,

75015 Paris, France

rosa.vargas@aphp.fr

ORCID number: 0000-0002-4169-0680 


\section{Abstract:}

The thick ascending limb plays a central role in human renal physiology, participating in sodium reabsorption, urine concentrating mechanisms, calcium and magnesium homeostasis, bicarbonate and ammonium homeostasis, and uromodulin synthesis. This review aims to illustrate the importance of these roles from a pathophysiological point of view by describing the interactions of the key proteins of this segment and by discussing how recently identified and long-known hereditary diseases affect this segment. The descriptions of two recently described salt-losing tubulopathies, transient antenatal Bartter syndrome and HELIX syndrome, which are caused by mutations in MAGED2 and CLDN10 genes, respectively, highlight the role of new players in the modulation of sodium reabsorption the thick ascending limb.

\section{Keywords}

Thick ascending limb, sodium reabsorption, claudin-10, MAGED2, HELIX syndrome, transient antenatal Bartter syndrome

\section{The Thick Ascending Limb:}

The thick ascending limb (TAL) occupies a central anatomic and functional position in human renal system. The TAL has four main roles: First, it functions to maintain homeostasis of extracellular fluid through sodium reabsorption; as TAL exhibits a very low permeability to water, sodium reabsorption without water contributes to the generation of a cortico-medullar osmotic gradient required for the vasopressindependent absorption of water by the collecting duct and concentration of urine Second, the TAL is critical to calcium and magnesium homeostasis. Third, the TAL contributes to bicarbonate and ammonium homeostasis. Fourth, the TAL regulates urinary protein composition through the synthesis of uromodulin. This review will discuss the functions of the TAL in the light of recently described diseases that affect this segment. After a summary of the main functions of the TAL, I will focus on the more recently described physiopathological aspects. For further reading on TAL anatomy and functions, I suggest two major reviews by Mount and by Bankir [1, 2].

The loop of Henle encompasses the thin descending and ascending limbs and the TAL. The TAL begins after the thin ascending limb and extends from the medulla to 
the cortex, where it meets its parent glomerulus at the vascular pole constituting part of the macula densa (Figure 1A). The size of the TAL and the ratio of medullary to cortical segments are functions of its origin: Superficial nephrons have longer cortical and shorter medullary TALs, whereas juxtamedullary nephrons have almost no cortical TALs and long medullary TALs. Epithelial cells lining the TAL are characterized by tall interdigitations and numerous mitochondria within extensively invaginated basolateral membranes, reflecting the high metabolic activity.

\section{Transepithelial Sodium Reabsorption:}

The TAL reabsorbs approximately $30 \%$ of filtered $\mathrm{NaCl}$ (Figure 2). Half of this reabsorption is transepithelial and depends on the conjoined action of two apical proteins, the cotransporter NKCC2 and the potassium channel Kir1.1 (also known as ROMK), and on four basolateral proteins, Na-K-ATPase, the chloride channels CIC$\mathrm{Ka}$ and $\mathrm{ClC}-\mathrm{Kb}$, and their subunit barttin $[3,4,5]$. The furosemide-sensitive cotransporter NKCC2, encoded by the SLC12A1 gene, transports in an electroneutral way one $\mathrm{Na}^{+}$ion, one $\mathrm{K}^{+}$ion, and two $\mathrm{Cl}^{-}$ions. NKCC2 has three isoforms $(A, B$, and $F)$ that arise due to alternative splicing of exon 4 . These isoforms have different affinities for $\mathrm{Cl}^{-}$and different patterns of expression: The lowaffinity/high-capacity $F$ isoform is expressed in the inner medulla, the intermediateaffinity $A$ isoform is expressed in the outer medulla, and the high-affinity/low-capacity $B$ isoform is expressed in the cortical segment. This differential expression is consistent with a higher tubular $\mathrm{Cl}^{-}$concentration and transport rate in the medullary TAL compared with the cortical TAL $[6,7]$. The limiting factor for NKCC2 function is $\mathrm{K}^{+}$availability, which is provided by the potassium channel Kir1.1, which recycles the $\mathrm{K}^{+}$across the apical membrane. On the basolateral side, $\mathrm{Na}^{+}$exits the cell via the Na-K-ATPase, which is abundant in the TAL and generates the $\mathrm{Na}^{+}$gradient; $\mathrm{Cl}^{-}$ exits due to the activity of the chloride channels CICKa and CLCKb and their subunit barttin. These two chloride channels are both expressed in the cortical TAL, whereas only CLCKb is expressed in the medullary TAL [5].

In a minor proportion, transepithelial $\mathrm{Na}^{+}$reabsorption occurs via the $\mathrm{Na}^{+} / \mathrm{H}^{+}$ exchanger NHE3. It is expressed in the apical membrane of the proximal tubule and TAL and is important for bicarbonate reabsorption. Recently, study of a constitutive tubule-specific NHE3 knockout mouse model demonstrated the contribution of this $\mathrm{Na}^{+} / \mathrm{H}^{+}$exchanger in the $\mathrm{Na}^{+}$homeostasis and urinary concentration mechanism. 
Mice lacking renal NHE3 have significantly elevated fluid intake, urinary flow rate, urinary sodium/creatinine, and $\mathrm{pH}$ and significantly lower urine osmolality and GFR than wild-type controls. Interestingly, the mice that lack NHE3 also have a urinary concentration defect after water deprivation that becomes more severe with a lowsodium diet. These data indicate that NHE3 in the medullary TAL contributes to some extent to the generation of the medullary interstitial gradient [8].

During this transepithelial $\mathrm{NaCl}$ reabsorption process, the hyperpolarization of the apical membrane and depolarization of the basolateral membrane by the activity of the $\mathrm{K}^{+}$and $\mathrm{Cl}^{-}$channels, respectively, generates a lumen-positive transepithelial potential that drives the paracellular reabsorption of divalent cations; this will be discussed further below.

\section{Paracellular Sodium Reabsorption:}

The tight junctions, which are complexes of structural and anchoring proteins, are the pillars of paracellular transport. Claudins, a group of integral membrane proteins, are important components of the tight junctions. Claudins are tetraspan proteins with intracellular $\mathrm{N}$ - and C-termini and two extracellular loops; the first loop is important for ion selectivity, and the second for interaction with other claudins. Interactions can occur between claudins of the same plasma membrane (cis interactions) or with claudins of the neighboring cell across the paracellular cleft (trans interactions); these interactions can happen with the same claudins (homophilic interactions) or with other claudins (heterophilic interactions). The complexes formed by claudins along the cell membranes act primarily as pore or barrier structures, defining permeability and selectivity of the paracellular space and the transepithelial electrical resistance [9].

The claudins $3,10 \mathrm{~b}, 14,16$, and 19 are heterogeneously expressed in different portions of the TAL $[10,11,12]$. In the inner stripe of the outer medulla (ISOM), claudin-10b is the only claudin present, whereas in the outer stripe of the outer medulla (OSOM) and in the cortex, claudins have a mosaic pattern of expression with tight junctions expressing either claudin-10b or claudins 3,16 , and 19 [13, 14]. It has been shown that tight junctions expressing claudin-10b are highly permeable to $\mathrm{Na}^{+}$, making the ISOM the seat of $50 \%$ of $\mathrm{Na}^{+}$reabsorption. As the tubular fluid arriving to the cortical TAL has been depleted in $\mathrm{NaCl}$, a backflow of $\mathrm{Na}^{+}$into the 
lumen along its concentration gradient via the paracellular tight junctions expressing claudin-10b occurs in this segment, which contributes to maintain the lumen-positive transepithelial potential.

\section{Hereditary Diseases Affecting $\mathrm{NaCl}$ Reabsorption (Table 1):}

Hereditary salt-losing tubulopathies due to anomalies in transepithelial sodium reabsorption in the TAL result in the five different types of Bartter syndrome. Type 1 is caused by mutations in the SLC12A1 gene, which encodes the NKCC2 cotransporter $[15,16]$. Type 2 results from mutations in $K C N J 1$, the gene encoding the apical potassium channel Kir1.1 [17]. Type 3 is related to mutations in the CLCNKB gene, which encodes the basolateral chloride channel CIC-Kb [18, 19]. Mutations in the BSND gene encoding the protein barttin lead to type 4a [20]. Lossof-function mutations of the two CLCNKA and CLCNKB genes (digenic disease) are responsible for type $4 \mathrm{~b}$ Bartter syndrome [21]. Finally, type 5 is related to mutations in MAGED2, which encodes a nuclear protein that affects the expression and function of sodium-chloride cotransporters including NKCC2 [22]. Type 5, which was recently described, will be discussed in detail in the following sections. Another hereditary salt-losing tubulopathy affecting the paracellular $\mathrm{Na}^{+}$reabsorption in the TAL has been identified recently: Mutations in the gene encoding claudin-10b are responsible for HELIX syndrome [23-25]. This new syndrome will be discussed in detail below.

\section{Paracellular Calcium and Magnesium Reabsorption:}

In the cortical and outer stripe of the outer medulla segments of the TAL, 50 to $60 \%$ of the filtered $\mathrm{Mg}^{2+}$ and approximately $20 \%$ of the filtered $\mathrm{Ca}^{2+}$ are reabsorbed by the paracellular pathway. This reabsorption depends on both the lumen-positive transepithelial potential generated by the $\mathrm{NaCl}$ reabsorption process and on the selective permeability to divalent cations due to the presence of claudin-16 and claudin-19 [26] (Figure 2). These two claudins have a cis interaction, which is critical to maintain this selectivity [26]. The paracellular permeability for $\mathrm{Ca}^{2+}$ and $\mathrm{Mg}^{2+}$ is also modulated by the interaction between claudin-14 and claudin-16. It has been shown that claudin-14 is absent in basal conditions and is upregulated after a highcalcium diet [14]. The expression of claudin-14 is positively regulated by the basolateral calcium sensing receptor CaSR, via a microRNA-dependent mechanism. 
High-calcium diets as well as allosteric CaSR-agonists trigger the inhibition of two microRNAs (miR-9 and miR-374) that normally suppress the expression of claudin14 [27]. Claudin-14 interferes with formation of claudin-16/claudin-19 complexes resulting in reduction in the permeability of $\mathrm{Ca}^{2+}$ and $\mathrm{Mg}^{2+}$ in the cortical TAL $[27,28]$. Furthermore, the phenotype of transgenic mice overexpressing claudin-14 in the TAL is characterized by a severe urinary loss of $\mathrm{Ca}^{2+}$ and $\mathrm{Mg}^{2+}[29]$.

\section{Hereditary Diseases Affecting $\mathrm{Ca}^{2+} \stackrel{2}{ }$ and $\mathrm{Mg}^{2+} \stackrel{\text { Reabsorption (Table 1): }}{ }$}

Mutations in genes encoding claudins 16 and 19 (CLDN16 and CLDN19, respectively), which encode the two proteins involved in paracellular magnesium and calcium reabsorption, are responsible for familial hypomagnesemia with hypercalciuria and nephrocalcinosis [30, 31]. Patients with CLDN19 mutations frequently display severe ocular abnormalities. Claudins 16 and 19 are also expressed in ameloblast tight junctions, and loss-of-function mutations of CLDN16 and CLDN19 are associated with amelogenesis imperfecta [32, 33].

Hereditary diseases affecting expression or function of CaSR or its partner proteins AP2 $\sigma 2$ and $\mathrm{Ga}_{11}$ are responsible of dysregulation of $\mathrm{Ca}^{2+}$ reabsorption, explaining the paradoxical clinical presentations of hypercalcemia with hypocalciuria in familial benign hypercalcemia (inactivating mutations) and the hypocalcemia with hypercalciuria in autosomal dominant hypocalcemia (activating mutations) [34]. A Bartter-like phenotype has been described in some patients harboring activating mutations [35, 36]; this association was initially named Bartter type 5. Nevertheless, this designation has been abandoned because it is observed in few patients with autosomal dominant hypocalcemia and in the current OMIM nomenclature the term Bartter type 5 refers to $\mathrm{X}$-linked transient Bartter syndrome.

The relevance of the role of claudin-14 in the modulation of $\mathrm{Ca}^{2+}$ and $\mathrm{Mg}^{2+}$ reabsorption is supported by genome-wide association studies. These analyses showed that common variants in the CLDN14 gene are associated with increased risk of kidney stones, reduced bone mineral density, and differential excretion of $\mathrm{Mg}^{2+}$ over $\mathrm{Ca}^{2+}$ in urine in the general population $[37,38,39]$. 


\section{Bicarbonate and Ammonium Transport:}

The TAL reabsorbs approximately $15 \%$ of filtered bicarbonate by a mechanism coupling apical $\mathrm{H}^{+}$secretion with basolateral exit of bicarbonate mediated by the apical sodium/hydrogen exchangers NHE2 (in the cortical TAL) and NHE3 (in the medullary $T A L$ ) and the basolateral chloride/bicarbonate exchanger $A E 2$ and the potassium/bicarbonate cotransporter KCC4. Bicarbonate reabsorption by the TAL is upregulated in acidosis and downregulated in metabolic alkalosis [40, 41].

The $\mathrm{NH}_{4}{ }^{+}$secreted in the proximal tubule is reabsorbed in the TAL. This reabsorption maintains its appropriate concentration in the medullary interstitium and allows subsequent secretion by the medullary collecting duct. The $\mathrm{NH}_{4}{ }^{+}$ion can take the place of $\mathrm{K}^{+}$in different transport systems because these two ions have similar ionic radii. Because of this similarity, $\mathrm{NH}_{4}{ }^{+}$can be transported through the apical membrane by $\mathrm{NKCC} 2$ or $\mathrm{K}^{+}$channels. The basolateral exit is mediated by the basolateral sodium/hydrogen exchanger NHE4, functioning in sodium/ammonium exchange mode. Due to the capacity of the TAL to reabsorb $\mathrm{NH}_{4}{ }^{+}$, the corticomedullary $\mathrm{NH}_{4}{ }^{+}$gradient is increased during acidosis [42].

\section{The Glycoprotein Uromodulin:}

Uromodulin, also known as Tamm-Horsfall protein, is exclusively produced by TAL cells and by cells in the first part of the distal convoluted tubule. The precursor peptide of uromodulin is translocated into the endoplasmic reticulum, where glycosylphosphatidylinositol and glycans are attached to the protein, and then this complex is anchored to the apical membrane. After subsequent proteolytic cleavage, it is secreted in the urine. Uromodulin is the most abundant protein in normal urine (50-150 mg/day). Interest in uromodulin has increased since the identification in 2002 of mutations in the gene encoding this protein $(U M O D)$ in patients with familial juvenile hyperuricemic nephropathy and medullary cystic kidney disease [43]. Uromodulin has other roles including protection against urinary tract infections and stone formation, regulation of ion transport, and immunomodulation [44]. Only the function related to ion transport will be discussed here. It has been shown that uromodulin increases the activity of the NKCC2 protein and the expression of the potassium channel Kir1.1 and, as a consequence, increases the tonicity of the medulla and the urinary concentration capacity $[45,46]$. In umod-knockout mice, 
which lack uromodulin, a defect in TAL reabsorption is associated with an increase of the luminal $\mathrm{NaCl}$ load to the macula densa reducing GFR through tubuloglomerular feedback and impaired urinary concentration ability after water deprivation. Similar to animal models of Bartter syndrome, these mice exhibit upregulation of NCC and $\mathrm{ENaC}$, proteins responsible for distal sodium reabsorption in the distal convoluted tubule and the collecting duct, respectively [47, 48]. UMOD mutations lead to defective trafficking of mutant uromodulin causing its retention in the endoplasmic reticulum with ensuing endoplasmic reticulum stress and a cascade leading to inflammatory cell infiltrates, tubular dysfunction, and interstitial fibrosis, which are characteristics of autosomal dominant tubulointerstitial kidney disease [49](Table 1).

\section{Novel Genetic Defects:}

\section{Transient antenatal Bartter syndrome (OMIM 300971)}

Molecular genetics: In 2016, Laghmani et al. performed exome sequencing on sample from one family in which three pregnancies with male offspring were complicated by transient antenatal Bartter syndrome and identified a nonsense mutation in the MAGED2 gene, located on the $X$ chromosome that co-segregated with the disease. Subsequent sequencing of other male patients with the same clinical phenotype or with acute recurrent polyhydramnios confirmed the association of MAGED2 mutations with transient antenatal Bartter syndrome. In these patients, Laghmani et al detected nine different mutations distributed along the MAGED2 gene; seven of them were truncating mutations. All affected patients were males and mutations segregated with the disease [22].

In our clinical experience, a diagnosis of Bartter syndrome types 1 to 4 was confirmed in $76 \%$ of cases of antenatal Bartter syndrome. The screening for mutations in MAGED2 gene in 42 probands without genetic characterization, allowed us to identify mutations in 17 probands from 16 families, which represents $9 \%$ of the cohort. Most of the identified MAGED2 variants were nonsense, frameshift, and splice site pathogenic variants, and only 2 of 15 detected variants had been previously described [50]. This spectrum of mutations is similar to that described by Laghmani et al.. Interestingly, in two of our families the index cases were females, 
with phenotypes comparable to those of males. In one of these families, the study of X-inactivation pattern (based on methylation-specific PCR) showed a highly skewed $X$-inactivation pattern with inactivation of the non-mutated allele. In asymptomatic heterozygous females from two additional families the mutated allele was inactive or there was no preferential $\mathrm{X}$-inactivation.

Clinical presentation: Patients described by Laghmani et al. presented with early and severe polyhydramnios (around 19 and 20 weeks of gestation) and were born prematurely with delivery between 22 and 34 weeks. In the neonatal period, they presented clinical characteristics of Bartter syndrome (Tables 1 and 2) with subsequent improvement. The duration of polyuria was between 0.5 to 6 weeks and the duration of mineral supplementation was between 1 month and 3 years [22].

We detected in our cohort of Bartter syndrome type 5 patients some characteristics not previously described. First, 12 of 16 patients in our cohort had weight and/or length percentiles for gestational age that were above the $90^{\text {th }}$ percentile; in 11 of these cases the ponderal index adapted to gestational age was normal, which allows classifying these cases as harmonious macrosomia. Secondly, we observed that patients with Bartter syndrome type 5 have normal or even high plasma chloride, contrasting with the presence of hypochloremia in the other forms of Bartter syndrome, particularly in Bartter syndrome type 3. Thirdly, when we compared the relationship between plasma sodium and chloride concentrations, the relationship was shifted upward in patients with MAGED2 mutations but downward in Bartter syndrome type 3 patients. Fourthly, we observed extra kidney manifestations affecting several systems, including central nervous and cardiovascular, in patients with Bartter syndrome type 5 [50]. Another patient with Bartter syndrome type 5 and cardiac abnormalities was described by Arthuis et al. [51]. The two last characteristics, suggest that it is possible that MAGE-D2 loss of function interferes with the expression of other proteins in the kidney and other organs. Table 2 summarizes the main characteristics of all the cases of transient Bartter syndrome patients described to date in the literature [22, 50-52]

Physiopathology: MAGE-D2 is a ubiquitous nucleolar protein that can be rapidly released to control cellular stress, allowing for rapid cell-cycle arrest [53]. In the rat 
kidney, it is expressed in the thin limb of Henle's loop, the TAL, the distal convoluted tubule, and collecting duct [54]. Laghmani et al. showed that MAGED2 functions to increase NKCC2 and NCC expression in the human TAL and distal convoluted tubule, respectively (Figure 2). MAGED2 has also been shown to interact with HSP40 and Gs-alpha proteins. HSP40 participates in quality process control as chaperone to protect proteins from degradation, and Gs-alpha activates adenylate cyclases inducing AMPc generation, which promotes NKCC2 and NCC insertion into the plasma membrane. In presence of mutated MAGE-D2, these interactions do not occur resulting in degradation and lower levels of these two critical cotransporters [22].

It is not clear why this form of Bartter syndrome is transient, but two hypotheses have been put forward. First, the interaction between HSP40 and MAGE-D2 could function to protect the cotransporters from degradation induced by tissue hypoxia that can occur during early pregnancy, a function that is not critical later in development. Second, Gs-alpha activity might be compensated for, resulting in greater sensitivity to vasopressin and reducing the dependence of Gsa on MAGE-D2 activity, as patients age [22]. Interestingly, recent work shows that MAGE-D2 expression is inducible after acute kidney injury or stress suggesting a role of this protein in postnatal kidney physiology [55]. Future studies are needed to better understand the molecular mechanisms and the role of MAGE-D2 in stress response within the kidney. The inclusion of the MAGED2 gene in the systematic genetic screening for antenatal Bartter syndrome is highly recommended to ensure optimal follow-up and genetic counselling.

\section{HELIX syndrome (OMIM 617671)}

Molecular genetics: In 2017, three different groups described patients harboring biallelic mutations in the gene that encodes claudin-10b using exome sequencing [23-25]. These patients were diagnosed with a new tubulopathy clinically characterized by renal hypokalemia, hypermagnesemia, and a trend to hypercalcemia and extra renal manifestations affecting the exocrine glands. The renal phenotype is similar to the phenotype previously described in mice with cldn10 deletion in the TAL. These mice presented with strongly reduced paracellular $\mathrm{Na}^{+}$ permeability that led to a urinary concentration defect accompanied by compensatory 
increases of $\mathrm{K}^{+}$and $\mathrm{H}^{+}$secretion as well as hypermagnesemia [56]. Despite these similarities, mice lacking claudin-10b in the TAL have nephrocalcinosis, which was absent in patients.

Two major isoforms are produced from the human CLDN10 gene (located on chromosome 13), isoforms $10 \mathrm{a}$ and 10b. They differ in their first extracellular segment and first transmembrane segment. As the first extracellular loop is important for ion selectivity, claudins $10 \mathrm{a}$ and $10 \mathrm{~b}$ exhibit different permeability properties. Indeed, claudin-10a has a proportion of amino acids with positive to negative charges of 7 to 1 defining a paracellular anion channel, and claudin-10b has a proportion of 4 to 5 resulting in strong permeability to all monovalent cations with preference for $\mathrm{Na}^{+}$, low permeability to divalent cations, and impermeability to large molecules and water $[13,57]$.

The expression of isoform 10a seems to be restricted to the kidney, whereas isoform $10 \mathrm{~b}$ is expressed in kidney, salivary glands, skin, sweat glands, brain, lung, and pancreas $[57,58,59]$. In the kidney, claudin-10a is exclusively expressed in the proximal tubule, and claudin-10b is expressed in the cortical and medullary segments of the TAL.

To date seven different mutations affecting $10 \mathrm{~b}$ isoform of the CLDN10 gene have been described (Figure 3A). Most of them are missense mutations. In vitro studies performed on six showed that they cause a partial or complete loss of function of claudin-10b. Mutants with mutations located on the first and second extracellular loops are partially retained inside the cell (p.Asn48Lys, p.Asp73Asn, and p.Pro149Arg) $[23,25]$.. Other mutants, with alterations located in transmembrane domains, are not observed in the cellular membrane (exon 4 deletion, p.Met1?, and p.Ser131Leu) [24, 25]. For some mutants (p.Asn48Lys, p.Asp73Asn, and p.Pro149Arg), the homophilic cis and trans interactions of claudin-10b have been studied. These analyses showed that these interactions are preserved but that the quality and/or quantity of interactions and assembly are impaired $[23,25]$.

Clinical presentation: To date 22 patients from seven families have been described who have this new claudinopathy, which is also known as HELIX syndrome [23] $[24,25,60]$. The main clinical and biochemical characteristics of these patients are 
summarized in Table 3. The renal phenotype of HELIX syndrome patients is characterized by electrolyte imbalance: Hypermagnesemia, renal hypokalaemia with secondary hyperaldosteronism, low blood pressure, and hypocalciuria are the most consistent traits. Hypermagnesemia seems to be most pronounced in children. In contrast, hypokalemia seems to be more frequent in adults. Dynamic studies performed on three patients showed that in basal conditions, patients have higher fractional excretions of sodium and chloride compared with controls. After furosemide treatment, fractional excretions of sodium and chloride increased to similar values in patients and controls, but the percentage of increase was significantly lower in patients, consistent with blunted natriuretic and chloruretic responses. Fractional excretions of calcium and magnesium were similar in patients and healthy subjects in basal conditions. After furosemide treatment, the fractional excretion of calcium increased significantly, but the increase was not as pronounced in patients as in controls, whereas the fractional excretion of magnesium increased to a greater extent in patients than in controls [24].

The extrarenal phenotype of patients with HELIX syndrome is characterized by manifestations related to exocrine glands. First, there are dermatological manifestations: A hypohidrosis with intolerance to heat has been frequently reported. Although this trait was not noted initially in the two patients described by Bongers et al. [23], it was confirmed subsequently [61]. In some patients, dry skin with fine white scaling, predominantly on the arms and knees, and plantar keratoderma has been described; histologic examinations were consistent with ichthyosis with an increased number of dilated sweat glands. Skin abnormalities were not detected in patients described by Klar et al. and Meyer et al. [25, 60]. Second, an inability to produce tears or alacrima is present in almost all of the cases. Third, xerostomia with severe reduction of the watery component of saliva was detected in all patients. We analyzed saliva from patients and observed a reduction of $98 \%$ relative to normal fluid secretion [24]. Finally, patients can present severe enamel wear, probably related to the absence of saliva.

Physiopathology: In normal conditions in the TAL and salivary and sweat glands, the homophilic claudin-10b complex makes tight junctions selectively permeable by $\mathrm{Na}^{+}$ (Figure 2 and $3 \mathrm{~B}$ ). The loss of function of claudin-10b should reduce the $\mathrm{Na}^{+}$ 
reabsorption in the TAL by the paracellular component and lead to a compensatory increase of reabsorption in the more distal nephron segments. This explains the $\mathrm{K}^{+}$ and $\mathrm{H}^{+}$loss in HELIX syndrome patients as it does in patients with other salt-losing tubulopathies. Hypermagnesemia and hypocalciuria are explained by exaggerated paracellular reabsorption of $\mathrm{Mg}^{2+}$ and $\mathrm{Ca}^{2+}$ in the TAL. In mice lacking claudin-10b in the TAL, increased expression of claudin-16 and -19 is observed in the inner stripe of the outer medulla, and these animals have hypermagnesemia [56] [62]. With the loss of claudin-10b function, the loss of $\mathrm{Na}^{+}$reabsorption by the inner stripe of the outer medulla segment is compensated for by expression of claudin-16 and claudin-19, and the function of $\mathrm{Na}^{+}$reabsorption is replaced by increased reabsorption of $\mathrm{Mg}^{2+}$ and $\mathrm{Ca}^{2+}$.

In the salivary, sweat, and lacrimal gland epithelia, $\mathrm{Na}^{+}$and $\mathrm{Cl}^{-}$are secreted via the basolateral cotransporter NKCC1 and the apical chloride channel CFTR, creating a lumen-negative transepithelial potential difference that allows the paracellular passive secretion of $\mathrm{Na}^{+}$via claudin-10b acting as a channel. This is associated with a transcellular water secretion through the aquaporin-5 water channels $[63,64,65$, $66,67]$. The loss of function of claudin-10b in these glands results in loss of $\mathrm{Na}^{+}$and water secretion in saliva, sweat, and tears explaining the main extrarenal symptoms observed. The characteristics of the HELIX syndrome indicate that claudin-10b is essential for sodium transport in the kidney and exocrine glands. Further studies are necessary to better understand the variability of clinical manifestations and their modifications with age in these patients.

\section{Other physiopathologies resulting from TAL dysfunction}

Recent works shed light on the regulation and interactions of proteins expressed in the TAL: First, a decrease of claudin-14 expression by activation of the PTH receptor has been reported [68]. Second, expression of CaSR is regulated by the transcription factor HNF1B: Using promoter assays Kompatscher et al., showed an increase in CaSR expression in presence of HNF1beta and a decrease of its expression when the DNA binding was blocked. They also observed a down regulation of the CaSR as well as of claudin-19 and of claudin-10b in hnf1b-knockout mice [69]. This likely contributes to the tubular phenotypes observed in patients with HNF1B mutations. Finally, CaSR may modulate the excretion of uromodulin in the urine. Indeed it has 
been shown, in vitro and in mice, that the inactivation of CaSR increases uromodulin excretion, probably through post-translational control of its trafficking and cAMP levels in TAL [70]. All these interactions illustrate the complex interrelationships of proteins expressed in the TAL, and further studies will lead to a better understanding of the normal and pathological physiology of the human TAL.

Other types of interactions, such as those between different nephron segments, seem to play roles in the physiopathologies of known diseases of the TAL as shown by the recent work of $\mathrm{Hou}$ et al. [71]. These authors showed that phosphorylated claudin-16 is present in luminal membrane of the distal convoluted tubule, where it interacts with the calcium channel Trpv5 to increase the transcellular calcium reabsorption. A claudin-16 mutant (p.Thr303Arg), described in patients with familial hypomagnesemia with hypercalciuria and nephrocalcinosis who have severe hypercalciuria and mild hypomagnesemia [72], is not correctly phosphorylated and is unable to facilitate transcellular $\mathrm{Ca}^{2+}$ reabsorption via Trpv5. Both these characteristics may contribute to the hypercalciuria observed in patients. Hou et al. also showed that a high-calcium diet reduces claudin-16 phosphorylation at threonine 303 in mouse distal convoluted tubules via the PTH signaling cascade. This work indicates that the PTH-to-claudin-16 phosphorylation pathway could block renal calcium wasting through the regulation of the abundance of Trpv5 channel.

It is possible that proteins implicated in tubulopathies affecting other segments play a functional role in the TAL. The basolateral potassium channel Kir4.1, encoded for by the KCNJ10 gene, is implicated in EAST/SeSAME syndrome [73, 74]. This syndrome is associated with neurologic manifestations and a tubulopathy with the same characteristics of Gitelman syndrome. In the distal convoluted tubule, where Kir4.1 is highly expressed, Kir4.1 forms heterotetramers with Kir5.1 that function is to recycle potassium assuring $\mathrm{Na-K}-\mathrm{ATPase}$ activity and generating a negative membrane potential. It has been shown that the loss of function of Kir4.1 diminishes activity of apical NCC. Although these two channels are expressed in the TAL, Zhang et al. have shown that the disruption of Kir.4.1 function in mice does not have a significant effect on NKCC2 expression or on the membrane potential of the TAL due to compensation by other basolateral $\mathrm{K}$ channels [75]. Nevertheless, we cannot exclude the possibility that this channel plays a role in other species or as a compensatory 
mechanism in situations that have not been explored. Along the same line, and taking into account the central role of the basolateral Na-K-ATPase, we speculate that the dysfunction of the subunits of this pump, ATP1A1 and FXYD2, affect TAL function. These two proteins are expressed in all the tubular segments, but currently they are only implicated in magnesium reabsorption in the distal convoluted tubule $[76,77]$.

It is noteworthy that patients with two of the hereditary diseases affecting proteins of the TAL very frequently develop chronic kidney disease (CKD). Patients with familial hypomagnesemia with hypercalciuria and nephrocalcinosis (FHHNC) often develop CKD, and approximately one-third of the patients reach end-stage kidney disease during adolescence [78, 79]. In autosomal dominant tubulointerstitial kidney disease due to UMOD mutations, the prevalence of CKD is very high; in a recent international study, it was $90 \%$ and end-stage kidney disease was observed in $44 \%$ of cases [80]. In the other hereditary diseases affecting TAL, CKD is less frequent, but it has been described in almost all of them. It has been described in patients with all types of Bartter syndrome; in our experience the proportion of patients with moderate to severe kidney disease is higher in patients with types 1 and 4 than other types [19]. In autosomal dominant hypocalcemia, around a third of patients have nephrocalcinosis often aggravated by treatment with vitamin $\mathrm{D}$ and calcium to correct the hypocalcemia, and in some cases CKD has been described [34, 81]. Finally 6 of 22 patients with HELIX syndrome have CKD.

Although mechanisms of CKD are established in ADTKD and are linked to inflammatory and apoptosis processes associated with intracellular accumulation of mutant uromodulin, the pathogenesis of CKD in other diseases is less clear. In FHHNC, no correlation between the degree of nephrocalcinosis and CKD progression has been observed [78, 79]. In Bartter syndrome, several mechanisms have been suggested including chronic stimulation of the renin-angiotensin system, dehydration episodes, prematurity, nephrocalcinosis, long-term nonsteroidal antiinflammatory drug treatment, and chronic hypokalemia. In HELIX syndrome, the kidney biopsy of one patient showed fibrosis predominant at the superficial cortex, slight tubular dilatation, and more intense staining of the juxtaglomerular apparatus with an anti-renin antibody than in control [24]. As in other salt losing tubulopathies, mechanisms such as stimulation of the renin-angiotensin system and chronic 
hypokalemia likely contribute to CKD in subjects with HELIX syndrome. Further studies and prospective follow-up of cohorts of patients with these diseases are necessary to better understand the pathogenesis of CKD in most of hereditary TAL diseases.

\section{Conclusions:}

The recent description of two new syndromes affecting sodium reabsorption in the TAL as well as recent studies that have revealed how proteins expressed in this segment are regulated and interact illustrate the central role of the TAL in the maintenance of extracellular fluid and magnesium and calcium homeostasis. Although the main mechanisms of TAL functions are well established, the identification of new hereditary diseases has introduced new aspects in the comprehension of interactions and regulation of proteins expressed in this segment. Further studies and follow-up of patients will increase our understanding of the pathophysiological implications and the natural history of both HELIX and transient antenatal Bartter syndromes.

\section{References}

1. Mount, D.B. (2014) Thick ascending limb of the loop of Henle. Clin J Am Soc Nephrol 9, 1974-86.

2. Bankir, L., Figueres, L., Prot-Bertoye, C., Bouby, N., Crambert, G., Pratt, J.H. and Houillier, P. (2020) Medullary and cortical thick ascending limb: similarities and differences. Am J Physiol Renal Physiol 318, F422-F442.

3. Bazua-Valenti, S., Castaneda-Bueno, M. and Gamba, G. (2016) Physiological role of SLC12 family members in the kidney. Am J Physiol Renal Physiol 311, F131-44.

4. Welling, P.A. and Ho, K. (2009) A comprehensive guide to the ROMK potassium channel: form and function in health and disease. Am J Physiol Renal Physiol 297, F849-63.

5. Fahlke, C. and Fischer, M. (2010) Physiology and pathophysiology of ClCK/barttin channels. Front Physiol 1, 155.

6. Castrop, H. and Schnermann, J. (2008) Isoforms of renal Na-K-2Cl cotransporter NKCC2: expression and functional significance. Am J Physiol Renal Physiol 295, F859-66.

7. Carota, I., Theilig, F., Oppermann, M., Kongsuphol, P., Rosenauer, A., Schreiber, R., Jensen, B.L., Walter, S., Kunzelmann, K. and Castrop, H. (2010) Localization and functional characterization of the human NKCC2 isoforms. Acta Physiol (Oxf) 199, 327-38. 
8. Fenton, R.A., Poulsen, S.B., de la Mora Chavez, S., Soleimani, M., Dominguez Rieg, J.A. and Rieg, T. (2017) Renal tubular NHE3 is required in the maintenance of water and sodium chloride homeostasis. Kidney Int 92, 397-414.

9. Tsukita, S., Tanaka, H. and Tamura, A. (2019) The Claudins: From Tight Junctions to Biological Systems. Trends Biochem Sci 44, 141-152.

10. Gong, Y. and Hou, J. (2017) Claudins in barrier and transport function-the kidney. Pflugers Arch 469, 105-113.

11. Muto, S. (2017) Physiological roles of claudins in kidney tubule paracellular transport. Am J Physiol Renal Physiol 312, F9-F24.

12. Prot-Bertoye, C. and Houillier, P. (2020) Claudins in Renal Physiology and Pathology. Genes (Basel) 11.

13. Milatz, S. and Breiderhoff, T. (2017) One gene, two paracellular ion channelsclaudin-10 in the kidney. Pflugers Arch 469, 115-121.

14. Plain, A., Wulfmeyer, V.C., Milatz, S., Klietz, A., Hou, J., Bleich, M. and Himmerkus, N. (2016) Corticomedullary difference in the effects of dietary $\mathrm{Ca}(2)(+)$ on tight junction properties in thick ascending limbs of Henle's loop. Pflugers Arch 468, 293-303.

15. Simon, D.B., Karet, F.E., Hamdan, J.M., DiPietro, A., Sanjad, S.A. and Lifton, R.P. (1996) Bartter's syndrome, hypokalaemic alkalosis with hypercalciuria, is caused by mutations in the Na-K-2Cl cotransporter NKCC2. Nat Genet 13, 183-8.

16. Vargas-Poussou, R., Feldmann, D., Vollmer, M., Konrad, M., Kelly, L., van den Heuvel, L.P., Tebourbi, L., Brandis, M., Karolyi, L., Hebert, S.C., Lemmink, H.H., Deschenes, G., Hildebrandt, F., Seyberth, H.W., Guay-Woodford, L.M., Knoers, N.V. and Antignac, C. (1998) Novel molecular variants of the Na-K-2Cl cotransporter gene are responsible for antenatal Bartter syndrome. Am J Hum Genet 62, 133240 .

17. Simon, D.B., Karet, F.E., Rodriguez-Soriano, J., Hamdan, J.H., DiPietro, A., Trachtman, H., Sanjad, S.A. and Lifton, R.P. (1996) Genetic heterogeneity of Bartter's syndrome revealed by mutations in the K+ channel, ROMK. Nat Genet $14,152-6$.

18. Simon, D.B., Bindra, R.S., Mansfield, T.A., Nelson-Williams, C., Mendonca, E., Stone, R., Schurman, S., Nayir, A., Alpay, H., Bakkaloglu, A., Rodriguez-Soriano, J., Morales, J.M., Sanjad, S.A., Taylor, C.M., Pilz, D., Brem, A., Trachtman, H., Griswold, W., Richard, G.A., John, E. and Lifton, R.P. (1997) Mutations in the chloride channel gene, CLCNKB, cause Bartter's syndrome type III. Nat Genet 17, 171-8.

19. Seys, E., Andrini, O., Keck, M., Mansour-Hendili, L., Courand, P.Y., Simian, C., Deschenes, G., Kwon, T., Bertholet-Thomas, A., Bobrie, G., Borde, J.S., BourdatMichel, G., Decramer, S., Cailliez, M., Krug, P., Cozette, P., Delbet, J.D., Dubourg, L., Chaveau, D., Fila, M., Jourde-Chiche, N., Knebelmann, B., Lavocat, M.P., Lemoine, S., Djeddi, D., Llanas, B., Louillet, F., Merieau, E., Mileva, M., Mota-Vieira, L., Mousson, C., Nobili, F., Novo, R., Roussey-Kesler, G., Vrillon, I., Walsh, S.B., Teulon, J., Blanchard, A. and Vargas-Poussou, R. (2017) Clinical and Genetic Spectrum of Bartter Syndrome Type 3. J Am Soc Nephrol 28, 2540-2552.

20. Birkenhager, R., Otto, E., Schurmann, M.J., Vollmer, M., Ruf, E.M., Maier-Lutz, I., Beekmann, F., Fekete, A., Omran, H., Feldmann, D., Milford, D.V., Jeck, N., Konrad, M., Landau, D., Knoers, N.V., Antignac, C., Sudbrak, R., Kispert, A. and Hildebrandt, F. (2001) Mutation of BSND causes Bartter syndrome with sensorineural deafness and kidney failure. Nat Genet 29, 310-4. 
21. Schlingmann, K.P., Konrad, M., Jeck, N., Waldegger, P., Reinalter, S.C., Holder, M., Seyberth, H.W. and Waldegger, S. (2004) Salt wasting and deafness resulting from mutations in two chloride channels. N Engl J Med 350, 1314-9.

22. Laghmani, K., Beck, B.B., Yang, S.S., Seaayfan, E., Wenzel, A., Reusch, B., Vitzthum, H., Priem, D., Demaretz, S., Bergmann, K., Duin, L.K., Gobel, H., Mache, C., Thiele, H., Bartram, M.P., Dombret, C., Altmuller, J., Nurnberg, P., Benzing, T., Levtchenko, E., Seyberth, H.W., Klaus, G., Yigit, G., Lin, S.H., Timmer, A., de Koning, T.J., Scherjon, S.A., Schlingmann, K.P., Bertrand, M.J., Rinschen, M.M., de Backer, O., Konrad, M. and Komhoff, M. (2016) Polyhydramnios, Transient Antenatal Bartter's Syndrome, and MAGED2 Mutations. N Engl J Med 374, 1853-63.

23. Bongers, E., Shelton, L.M., Milatz, S., Verkaart, S., Bech, A.P., Schoots, J., Cornelissen, E.A.M., Bleich, M., Hoenderop, J.G.J., Wetzels, J.F.M., Lugtenberg, D. and Nijenhuis, T. (2017) A Novel Hypokalemic-Alkalotic Salt-Losing Tubulopathy in Patients with CLDN10 Mutations. J Am Soc Nephrol 28, 3118-3128.

24. Hadj-Rabia, S., Brideau, G., Al-Sarraj, Y., Maroun, R.C., Figueres, M.L., LeclercMercier, S., Olinger, E., Baron, S., Chaussain, C., Nochy, D., Taha, R.Z., Knebelmann, B., Joshi, V., Curmi, P.A., Kambouris, M., Vargas-Poussou, R., Bodemer, C., Devuyst, O., Houillier, P. and El-Shanti, H. (2018) Multiplex epithelium dysfunction due to CLDN10 mutation: the HELIX syndrome. Genet Med 20, 190-201.

25. Klar, J., Piontek, J., Milatz, S., Tariq, M., Jameel, M., Breiderhoff, T., Schuster, J., Fatima, A., Asif, M., Sher, M., Mabert, K., Fromm, A., Baig, S.M., Gunzel, D. and Dahl, N. (2017) Altered paracellular cation permeability due to a rare CLDN10B variant causes anhidrosis and kidney damage. PLoS Genet 13, e1006897.

26. Hou, J., Renigunta, A., Konrad, M., Gomes, A.S., Schneeberger, E.E., Paul, D.L., Waldegger, S. and Goodenough, D.A. (2008) Claudin-16 and claudin-19 interact and form a cation-selective tight junction complex. J Clin Invest 118, 619-28.

27. Gong, Y., Renigunta, V., Himmerkus, N., Zhang, J., Renigunta, A., Bleich, M. and Hou, J. (2012) Claudin-14 regulates renal $\mathrm{Ca}(+)(+)$ transport in response to CaSR signalling via a novel microRNA pathway. Embo J 31, 1999-2012.

28. Dimke, H., Desai, P., Borovac, J., Lau, A., Pan, W. and Alexander, R.T. (2013) Activation of the $\mathrm{Ca}(2+)$-sensing receptor increases renal claudin-14 expression and urinary $\mathrm{Ca}(2+)$ excretion. Am J Physiol Renal Physiol 304, F761-9.

29. Gong, Y. and Hou, J. (2014) Claudin-14 underlies $\mathrm{Ca}(+)(+)$-sensing receptormediated $\mathrm{Ca}(+)(+)$ metabolism via NFAT-microRNA-based mechanisms. J Am Soc Nephrol 25, 745-60.

30. Simon, D.B., Lu, Y., Choate, K.A., Velazquez, H., Al-Sabban, E., Praga, M., Casari, G., Bettinelli, A., Colussi, G., Rodriguez-Soriano, J., McCredie, D., Milford, D., Sanjad, S. and Lifton, R.P. (1999) Paracellin-1, a renal tight junction protein required for paracellular Mg2+ resorption. Science 285, 103-6.

31. Konrad, M., Schaller, A., Seelow, D., Pandey, A.V., Waldegger, S., Lesslauer, A., Vitzthum, H., Suzuki, Y., Luk, J.M., Becker, C., Schlingmann, K.P., Schmid, M., Rodriguez-Soriano, J., Ariceta, G., Cano, F., Enriquez, R., Juppner, H., Bakkaloglu, S.A., Hediger, M.A., Gallati, S., Neuhauss, S.C., Nurnberg, P. and Weber, S. (2006) Mutations in the tight-junction gene claudin 19 (CLDN19) are associated with renal magnesium wasting, renal failure, and severe ocular involvement. Am J Hum Genet 79, 949-57.

32. Bardet, C., Courson, F., Wu, Y., Khaddam, M., Salmon, B., Ribes, S., Thumfart, J., Yamaguti, P.M., Rochefort, G.Y., Figueres, M.L., Breiderhoff, T., Garcia-Castano, A., Vallee, B., Le Denmat, D., Baroukh, B., Guilbert, T., Schmitt, A., Masse, J.M., Bazin, 
D., Lorenz, G., Morawietz, M., Hou, J., Carvalho-Lobato, P., Manzanares, M.C., Fricain, J.C., Talmud, D., Demontis, R., Neves, F., Zenaty, D., Berdal, A., Kiesow, A., Petzold, M., Menashi, S., Linglart, A., Acevedo, A.C., Vargas-Poussou, R., Muller, D., Houillier, P. and Chaussain, C. (2016) Claudin-16 Deficiency Impairs Tight Junction Function in Ameloblasts, Leading to Abnormal Enamel Formation. J Bone Miner Res 31, 498-513.

33. Yamaguti, P.M., Neves, F.A., Hotton, D., Bardet, C., de La Dure-Molla, M., Castro, L.C., Scher, M.D., Barbosa, M.E., Ditsch, C., Fricain, J.C., de La Faille, R., Figueres, M.L., Vargas-Poussou, R., Houillier, P., Chaussain, C., Babajko, S., Berdal, A. and Acevedo, A.C. (2017) Amelogenesis imperfecta in familial hypomagnesaemia and hypercalciuria with nephrocalcinosis caused by CLDN19 gene mutations. J Med Genet 54, 26-37.

34. Hannan, F.M., Babinsky, V.N. and Thakker, R.V. (2016) Disorders of the calciumsensing receptor and partner proteins: insights into the molecular basis of calcium homeostasis. J Mol Endocrinol 57, R127-42.

35. Watanabe, S., Fukumoto, S., Chang, H., Takeuchi, Y., Hasegawa, Y., Okazaki, R., Chikatsu, N. and Fujita, T. (2002) Association between activating mutations of calcium-sensing receptor and Bartter's syndrome. Lancet 360, 692-4.

36. Vargas-Poussou, R., Huang, C., Hulin, P., Houillier, P., Jeunemaitre, X., Paillard, M., Planelles, G., Dechaux, M., Miller, R.T. and Antignac, C. (2002) Functional characterization of a calcium-sensing receptor mutation in severe autosomal dominant hypocalcemia with a Bartter-like syndrome. J Am Soc Nephrol 13, 2259-66.

37. Thorleifsson, G., Holm, H., Edvardsson, V., Walters, G.B., Styrkarsdottir, U., Gudbjartsson, D.F., Sulem, P., Halldorsson, B.V., de Vegt, F., d'Ancona, F.C., den Heijer, M., Franzson, L., Christiansen, C., Alexandersen, P., Rafnar, T., Kristjansson, K., Sigurdsson, G., Kiemeney, L.A., Bodvarsson, M., Indridason, O.S., Palsson, R., Kong, A., Thorsteinsdottir, U. and Stefansson, K. (2009) Sequence variants in the CLDN14 gene associate with kidney stones and bone mineral density. Nat Genet 41, 926-30.

38. Guha, M., Bankura, B., Ghosh, S., Pattanayak, A.K., Ghosh, S., Pal, D.K., Puri, A., Kundu, A.K. and Das, M. (2015) Polymorphisms in CaSR and CLDN14 Genes Associated with Increased Risk of Kidney Stone Disease in Patients from the Eastern Part of India. PLoS One 10, e0130790.

39. Corre, T., Olinger, E., Harris, S.E., Traglia, M., Ulivi, S., Lenarduzzi, S., Belge, H., Youhanna, S., Tokonami, N., Bonny, O., Houillier, P., Polasek, O., Deary, I.J., Starr, J.M., Toniolo, D., Gasparini, P., Vollenweider, P., Hayward, C., Bochud, M. and Devuyst, 0. (2017) Common variants in CLDN14 are associated with differential excretion of magnesium over calcium in urine. Pflugers Arch 469, 91-103.

40. Good, D.W. (1993) The thick ascending limb as a site of renal bicarbonate reabsorption. Semin Nephrol 13, 225-35.

41. Wang, T., Hropot, M., Aronson, P.S. and Giebisch, G. (2001) Role of NHE isoforms in mediating bicarbonate reabsorption along the nephron. Am J Physiol Renal Physiol 281, F1117-22.

42. Weiner, I.D. and Verlander, J.W. (2017) Ammonia Transporters and Their Role in Acid-Base Balance. Physiol Rev 97, 465-494.

43. Hart, T.C., Gorry, M.C., Hart, P.S., Woodard, A.S., Shihabi, Z., Sandhu, J., Shirts, B., $\mathrm{Xu}$, L., Zhu, H., Barmada, M.M. and Bleyer, A.J. (2002) Mutations of the UMOD gene 
are responsible for medullary cystic kidney disease 2 and familial juvenile hyperuricaemic nephropathy. J Med Genet 39, 882-92.

44. Devuyst, O., Olinger, E. and Rampoldi, L. (2017) Uromodulin: from physiology to rare and complex kidney disorders. Nat Rev Nephrol 13, 525-544.

45. Mutig, K., Kahl, T., Saritas, T., Godes, M., Persson, P., Bates, J., Raffi, H., Rampoldi, L., Uchida, S., Hille, C., Dosche, C., Kumar, S., Castaneda-Bueno, M., Gamba, G. and Bachmann, S. (2011) Activation of the bumetanide-sensitive $\mathrm{Na}+, \mathrm{K}+, 2 \mathrm{Cl}-$ cotransporter (NKCC2) is facilitated by Tamm-Horsfall protein in a chloridesensitive manner. J Biol Chem 286, 30200-10.

46. Renigunta, A., Renigunta, V., Saritas, T., Decher, N., Mutig, K. and Waldegger, S. (2011) Tamm-Horsfall glycoprotein interacts with renal outer medullary potassium channel ROMK2 and regulates its function. J Biol Chem 286, 2224-35.

47. Bachmann, S., Mutig, K., Bates, J., Welker, P., Geist, B., Gross, V., Luft, F.C., Alenina, N., Bader, M., Thiele, B.J., Prasadan, K., Raffi, H.S. and Kumar, S. (2005) Renal effects of Tamm-Horsfall protein (uromodulin) deficiency in mice. Am J Physiol Renal Physiol 288, F559-67.

48. Graham, L.A., Padmanabhan, S., Fraser, N.J., Kumar, S., Bates, J.M., Raffi, H.S., Welsh, P., Beattie, W., Hao, S., Leh, S., Hultstrom, M., Ferreri, N.R., Dominiczak, A.F., Graham, D. and McBride, M.W. (2014) Validation of uromodulin as a candidate gene for human essential hypertension. Hypertension 63, 551-8.

49. Devuyst, O., Olinger, E., Weber, S., Eckardt, K.U., Kmoch, S., Rampoldi, L. and Bleyer, A.J. (2019) Autosomal dominant tubulointerstitial kidney disease. Nat Rev Dis Primers 5, 60.

50. Legrand, A., Treard, C., Roncelin, I., Dreux, S., Bertholet-Thomas, A., Broux, F., Bruno, D., Decramer, S., Deschenes, G., Djeddi, D., Guigonis, V., Jay, N., Khalifeh, T., Llanas, B., Morin, D., Morin, G., Nobili, F., Pietrement, C., Ryckewaert, A., Salomon, R., Vrillon, I., Blanchard, A. and Vargas-Poussou, R. (2018) Prevalence of Novel MAGED2 Mutations in Antenatal Bartter Syndrome. Clin J Am Soc Nephrol 13, 242-250.

51. Arthuis, C.J., Nizon, M., Komhoff, M., Beck, B.B., Riehmer, V., Bihouee, T., Bruel, A., Benbrik, N., Winer, N. and Isidor, B. (2018) A step towards precision medicine in management of severe transient polyhydramnios: MAGED2 variant. J Obstet Gynaecol 39, 395-397.

52. Meyer, M., Berrios, M. and Lo, C. (2018) Transient Antenatal Bartter's Syndrome: A Case Report. Front Pediatr 6, 51.

53. Florke Gee, R.R., Chen, H., Lee, A.K., Daly, C.A., Wilander, B.A., Fon Tacer, K. and Potts, P.R. (2020) Emerging roles of the MAGE protein family in stress response pathways. J Biol Chem 295, 16121-16155.

54. Limbutara, K., Chou, C.L. and Knepper, M.A. (2020) Quantitative Proteomics of All 14 Renal Tubule Segments in Rat. J Am Soc Nephrol 31, 1255-1266.

55. Valino-Rivas, L., Cuarental, L., Agustin, M., Husi, H., Cannata-Ortiz, P., Sanz, A.B., Mischak, H., Ortiz, A. and Sanchez-Nino, M.D. (2019) MAGE genes in the kidney: identification of MAGED2 as upregulated during kidney injury and in stressed tubular cells. Nephrol Dial Transplant 34, 1498-1507.

56. Breiderhoff, T., Himmerkus, N., Stuiver, M., Mutig, K., Will, C., Meij, I.C., Bachmann, S., Bleich, M., Willnow, T.E. and Muller, D. (2012) Deletion of claudin-10 (Cldn10) in the thick ascending limb impairs paracellular sodium permeability and leads to hypermagnesemia and nephrocalcinosis. Proc Natl Acad Sci U S A 109, 142416. 
57. Van Itallie, C.M., Rogan, S., Yu, A., Vidal, L.S., Holmes, J. and Anderson, J.M. (2006) Two splice variants of claudin-10 in the kidney create paracellular pores with different ion selectivities. Am J Physiol Renal Physiol 291, F1288-99.

58. Gunzel, D., Stuiver, M., Kausalya, P.J., Haisch, L., Krug, S.M., Rosenthal, R., Meij, I.C., Hunziker, W., Fromm, M. and Muller, D. (2009) Claudin-10 exists in six alternatively spliced isoforms that exhibit distinct localization and function. J Cell Sci 122, 1507-17.

59. Inai, T., Sengoku, A., Guan, X., Hirose, E., Iida, H. and Shibata, Y. (2005) Heterogeneity in expression and subcellular localization of tight junction proteins, claudin-10 and -15, examined by RT-PCR and immunofluorescence microscopy. Arch Histol Cytol 68, 349-60.

60. Meyers, N., Nelson-Williams, C., Malaga-Dieguez, L., Kaufmann, H., Loring, E., Knight, J., Lifton, R.P. and Trachtman, H. (2019) Hypokalemia Associated With a Claudin 10 Mutation: A Case Report. Am J Kidney Dis 73, 425-428.

61. Milatz, S. (2019) A Novel Claudinopathy Based on Claudin-10 Mutations. Int J Mol Sci 20.

62. Breiderhoff, T., Himmerkus, N., Drewell, H., Plain, A., Gunzel, D., Mutig, K., Willnow, T.E., Muller, D. and Bleich, M. (2018) Deletion of claudin-10 rescues claudin-16-deficient mice from hypomagnesemia and hypercalciuria. Kidney Int 93, 580-588.

63. Hong, J.H., Park, S., Shcheynikov, N. and Muallem, S. (2013) Mechanism and synergism in epithelial fluid and electrolyte secretion. Pflugers Arch 466, 148799.

64. Pedersen, A.M.L., Sorensen, C.E., Proctor, G.B., Carpenter, G.H. and Ekstrom, J. (2018) Salivary secretion in health and disease. J Oral Rehabil 45, 730-746.

65. Baker, O.J. (2016) Current trends in salivary gland tight junctions. Tissue Barriers 4, e1162348.

66. Cui, C.Y. and Schlessinger, D. (2015) Eccrine sweat gland development and sweat secretion. Exp Dermatol 24, 644-50.

67. Delporte, C. (2009) Aquaporins in secretory glands and their role in Sjogren's syndrome. Handb Exp Pharmacol, 185-201.

68. Sato, T., Courbebaisse, M., Ide, N., Fan, Y., Hanai, J.I., Kaludjerovic, J., Densmore, M.J., Yuan, Q., Toka, H.R., Pollak, M.R., Hou, J. and Lanske, B. (2017) Parathyroid hormone controls paracellular $\mathrm{Ca}(2+)$ transport in the thick ascending limb by regulating the tight-junction protein Claudin14. Proc Natl Acad Sci U S A 114, E3344-E3353.

69. Kompatscher, A., de Baaij, J.H.F., Aboudehen, K., Farahani, S., van Son, L.H.J., Milatz, S., Himmerkus, N., Veenstra, G.C., Bindels, R.J.M. and Hoenderop, J.G.J. (2018) Transcription factor HNF1beta regulates expression of the calciumsensing receptor in the thick ascending limb of the kidney. Am J Physiol Renal Physiol 315, F27-F35.

70. Tokonami, N., Olinger, E., Debaix, H., Houillier, P. and Devuyst, O. (2018) The excretion of uromodulin is modulated by the calcium-sensing receptor. Kidney Int 94, 882-886.

71. Hou, J., Renigunta, V., Nie, M., Sunq, A., Himmerkus, N., Quintanova, C., Bleich, M., Renigunta, A. and Wolf, M.T.F. (2019) Phosphorylated claudin-16 interacts with Trpv5 and regulates transcellular calcium transport in the kidney. Proc Natl Acad Sci U S A 116, 19176-19186. 
72. Muller, D., Kausalya, P.J., Claverie-Martin, F., Meij, I.C., Eggert, P., Garcia-Nieto, V. and Hunziker, W. (2003) A novel claudin 16 mutation associated with childhood hypercalciuria abolishes binding to ZO-1 and results in lysosomal mistargeting. Am J Hum Genet 73, 1293-301.

73. Bockenhauer, D., Feather, S., Stanescu, H.C., Bandulik, S., Zdebik, A.A., Reichold, M., Tobin, J., Lieberer, E., Sterner, C., Landoure, G., Arora, R., Sirimanna, T., Thompson, D., Cross, J.H., van't Hoff, W., Al Masri, O., Tullus, K., Yeung, S., Anikster, Y., Klootwijk, E., Hubank, M., Dillon, M.J., Heitzmann, D., Arcos-Burgos, M., Knepper, M.A., Dobbie, A., Gahl, W.A., Warth, R., Sheridan, E. and Kleta, R. (2009) Epilepsy, ataxia, sensorineural deafness, tubulopathy, and KCNJ10 mutations. N Engl J Med 360, 1960-70.

74. Scholl, U.I., Choi, M., Liu, T., Ramaekers, V.T., Hausler, M.G., Grimmer, J., Tobe, S.W., Farhi, A., Nelson-Williams, C. and Lifton, R.P. (2009) Seizures, sensorineural deafness, ataxia, mental retardation, and electrolyte imbalance (SeSAME syndrome) caused by mutations in KCNJ10. Proc Natl Acad Sci U S A 106, 5842-7.

75. Zhang, C., Wang, L., Su, X.T., Lin, D.H. and Wang, W.H. (2015) KCNJ10 (Kir4.1) is expressed in the basolateral membrane of the cortical thick ascending limb. Am J Physiol Renal Physiol 308, F1288-96.

76. de Baaij, J.H., Dorresteijn, E.M., Hennekam, E.A., Kamsteeg, E.J., Meijer, R., Dahan, K., Muller, M., van den Dorpel, M.A., Bindels, R.J., Hoenderop, J.G., Devuyst, O. and Knoers, N.V. (2015) Recurrent FXYD2 p.Gly41Arg mutation in patients with isolated dominant hypomagnesaemia. Nephrol Dial Transplant 30, 952-7.

77. Schlingmann, K.P., Bandulik, S., Mammen, C., Tarailo-Graovac, M., Holm, R., Baumann, M., Konig, J., Lee, J.J.Y., Drogemoller, B., Imminger, K., Beck, B.B., Altmuller, J., Thiele, H., Waldegger, S., Van't Hoff, W., Kleta, R., Warth, R., van Karnebeek, C.D.M., Vilsen, B., Bockenhauer, D. and Konrad, M. (2018) Germline De Novo Mutations in ATP1A1 Cause Renal Hypomagnesemia, Refractory Seizures, and Intellectual Disability. Am J Hum Genet 103, 808-816.

78. Konrad, M., Hou, J., Weber, S., Dotsch, J., Kari, J.A., Seeman, T., Kuwertz-Broking, E., Peco-Antic, A., Tasic, V., Dittrich, K., Alshaya, H.O., von Vigier, R.O., Gallati, S., Goodenough, D.A. and Schaller, A. (2008) CLDN16 genotype predicts renal decline in familial hypomagnesemia with hypercalciuria and nephrocalcinosis. J Am Soc Nephrol 19, 171-81.

79. Godron, A., Harambat, J., Boccio, V., Mensire, A., May, A., Rigothier, C., Couzi, L., Barrou, B., Godin, M., Chauveau, D., Faguer, S., Vallet, M., Cochat, P., Eckart, P., Guest, G., Guigonis, V., Houillier, P., Blanchard, A., Jeunemaitre, X. and VargasPoussou, R. (2012) Familial hypomagnesemia with hypercalciuria and nephrocalcinosis: phenotype-genotype correlation and outcome in 32 patients with CLDN16 or CLDN19 mutations. Clin J Am Soc Nephrol 7, 801-9.

80. Olinger, E., Hofmann, P., Kidd, K., Dufour, I., Belge, H., Schaeffer, C., Kipp, A., Bonny, O., Deltas, C., Demoulin, N., Fehr, T., Fuster, D.G., Gale, D.P., Goffin, E., Hodanova, K., Huynh-Do, U., Kistler, A., Morelle, J., Papagregoriou, G., Pirson, Y., Sandford, R., Sayer, J.A., Torra, R., Venzin, C., Venzin, R., Vogt, B., Zivna, M., Greka, A., Dahan, K., Rampoldi, L., Kmoch, S., Bleyer, A.J., Sr. and Devuyst, O. (2020) Clinical and genetic spectra of autosomal dominant tubulointerstitial kidney disease due to mutations in UMOD and MUC1. Kidney Int 98, 717-731.

81. Pearce, S.H., Williamson, C., Kifor, O., Bai, M., Coulthard, M.G., Davies, M., LewisBarned, N., McCredie, D., Powell, H., Kendall-Taylor, P., Brown, E.M. and Thakker, 
R.V. (1996) A familial syndrome of hypocalcemia with hypercalciuria due to mutations in the calcium-sensing receptor. N Engl J Med 335, 1115-22. 
Table 1. Hereditary diseases implicating proteins of the TAL

\begin{tabular}{|c|c|c|c|c|c|c|}
\hline $\begin{array}{l}\text { TAL function } \\
\text { affected }\end{array}$ & Disease & $\begin{array}{l}\text { OMIM } \\
\text { number }\end{array}$ & Gene & Protein & $\begin{array}{l}\text { Main clinical } \\
\text { characteristics }\end{array}$ & Main biological characteristics \\
\hline \multirow{4}{*}{$\begin{array}{l}\text { Sodium } \\
\text { reabsorption }\end{array}$} & Bartter type 1 & 601678 & SLC12A1 & NKCC2 & $\begin{array}{l}\text { Polyhydramnios, } \\
\text { prematurity, } \\
\text { failure to thrive, } \\
\text { polyuria, dehydration }\end{array}$ & $\begin{array}{l}\text { Hypokalemic alkalosis, hypochloremia } \\
\text { with normal plasma } \mathrm{Cl}^{-} / \mathrm{Na}^{+} \text {ratio, } \\
\text { secondary hyperaldosteronism, } \\
\text { hypercalciuria/nephrocalcinosis }\end{array}$ \\
\hline & Bartter type 2 & 241200 & KCNJ1 & Kir1.1 & $\begin{array}{l}\text { Polyhydramnios, } \\
\text { failure to thrive, } \\
\text { polyuria, dehydration }\end{array}$ & $\begin{array}{l}\text { Transient neonatal hyperkalemia, } \\
\text { hypokalemic alkalosis, hypochloremia } \\
\text { with normal plasma } \mathrm{Cl}^{-} / \mathrm{Na}^{+} \text {ratio, } \\
\text { secondary hyperaldosteronism, } \\
\text { hypercalciuria/nephrocalcinosis }\end{array}$ \\
\hline & Bartter type 3 & 607364 & CLCNKB & $\mathrm{ClC}-\mathrm{Kb}$ & $\begin{array}{l}\text { Variable onset } \\
\text { (antenatal/mild } \\
\text { polyhydramnios, } \\
\text { children), } \\
\text { failure to thrive, } \\
\text { polyuria, dehydration }\end{array}$ & $\begin{array}{l}\text { Hypokalemic alkalosis, secondary } \\
\text { hyperaldosteronism, hypochloremia } \\
\text { with decreased plasma } \mathrm{Cl} / \mathrm{Na}^{+} \text {ratio, } \\
\text { variable calcium excretion }\end{array}$ \\
\hline & Bartter type $4 a$ & 602522 & $B S N D$ & Barttin & $\begin{array}{l}\text { Polyhydramnios, } \\
\text { failure to thrive, }\end{array}$ & $\begin{array}{l}\text { Hypokalemic alkalosis, secondary } \\
\text { hyperaldosteronism, }\end{array}$ \\
\hline
\end{tabular}




\begin{tabular}{|c|c|c|c|c|c|c|}
\hline & & & & & $\begin{array}{l}\text { polyuria, dehydration, } \\
\text { deafness }\end{array}$ & $\begin{array}{l}\text { hypochloremia with decreased plasma } \\
\mathrm{Cl}^{-} / \mathrm{Na}^{+} \text {ratio, variable calcium excretion }\end{array}$ \\
\hline & Bartter type 4b & 613090 & $\begin{array}{l}\text { CLCNKA/ } \\
\text { CLCNKB }\end{array}$ & $\mathrm{ClC}-\mathrm{Ka} / \mathrm{ClC}-\mathrm{Kb}$ & $\begin{array}{l}\text { Polyhydramnios, } \\
\text { failure to thrive, } \\
\text { polyuria, dehydration, } \\
\text { deafness }\end{array}$ & $\begin{array}{l}\text { Hypokalemic alkalosis, secondary } \\
\text { hyperaldosteronism, } \\
\text { hypochloremia with decreased plasma } \\
\mathrm{Cl}^{-} / \mathrm{Na}^{+} \text {ratio, variable calcium excretion }\end{array}$ \\
\hline & Bartter type 5 & 300971 & MAGED2 & MAGE-D2 & $\begin{array}{l}\text { Polyhydramnios, } \\
\text { transient polyuria, } \\
\text { dehydration, } \\
\text { mMacrosomia }\end{array}$ & $\begin{array}{l}\text { Transient hypokalemic alkalosis with } \\
\text { secondary hyperaldosteronism, } \\
\text { increased plasma } \mathrm{Cl}^{-} / \mathrm{Na}^{+} \text {ratio }\end{array}$ \\
\hline & $\begin{array}{l}\text { HELIX } \\
\text { syndrome }\end{array}$ & 617671 & CLDN10 & Claudin-10b & $\begin{array}{l}\text { Hypohydrosis, } \\
\text { lachrymal } \\
\text { dysfunction, } \\
\text { ichtyosis, xerostomia }\end{array}$ & $\begin{array}{l}\text { Hypokalemia, hypermagnesemia, } \\
\text { secondary hyperaldosteronism }\end{array}$ \\
\hline $\begin{array}{l}\text { Calcium and } \\
\text { magnesium } \\
\text { reabsorption }\end{array}$ & $\begin{array}{l}\text { Familial } \\
\text { hypomagnesae } \\
\text { mia with } \\
\text { hypercalciuria } \\
\text { and } \\
\text { nephrocalcinosi } \\
\text { s (FHHNC) }\end{array}$ & 248250 & CLDN16 & Claudin-16 & $\begin{array}{l}\text { Polyuria, } \\
\text { urinary tract } \\
\text { infections, } \\
\text { muscle weakness, } \\
\text { tetany, } \\
\text { abdominal pain, } \\
\text { amelogenesis }\end{array}$ & $\begin{array}{l}\text { Hypercalciuria, } \\
\text { nephrocalcinosis/nephrolithiasis, } \\
\text { renal hypomagnesemia, } \\
\text { elevated serum iPTH, } \\
\text { decreased eGFR }\end{array}$ \\
\hline
\end{tabular}




\begin{tabular}{|c|c|c|c|c|c|}
\hline & & & & imperfecta & \\
\hline FHHNC & 248190 & CLDN19 & Claudin-19 & $\begin{array}{l}\text { Polyuria, } \\
\text { urinary tract } \\
\text { infections, } \\
\text { muscle weakness, } \\
\text { tetany, } \\
\text { abdominal pain, } \\
\text { ocular abnormalities, } \\
\text { amelogenesis } \\
\text { imperfecta }\end{array}$ & $\begin{array}{l}\text { Hypercalciuria, } \\
\text { nephrocalcinosis/nephrolithiasis, } \\
\text { renal hypomagnesemia, } \\
\text { elevated serum iPTH, } \\
\text { decreased eGFR }\end{array}$ \\
\hline $\begin{array}{l}\text { Familial } \\
\text { hypercalcemia } \\
\text { hypocalciuric } \\
(\mathrm{FHH}) \text { type } 1\end{array}$ & 145980 & CASR & $\begin{array}{l}\text { CaSR } \\
\text { inactivation }\end{array}$ & \multirow[t]{3}{*}{$\begin{array}{l}\text { Often asymptomatic, } \\
\text { headaches, fatigue, } \\
\text { cramps } \\
\text { Pancreatitis }\end{array}$} & \multirow[t]{3}{*}{$\begin{array}{l}\text { Hypercalcemia with normal or high } \\
\text { PTH, hypocalciuria }\end{array}$} \\
\hline FHH type 2 & 145981 & GNA11 & $\mathrm{G}_{11}$ & & \\
\hline FHH type 3 & 600740 & $A P 2 S 1$ & $\mathrm{AP} 2 \sigma 2$ & & \\
\hline $\begin{array}{l}\text { Autosomal } \\
\text { dominant } \\
\text { hypocalcemia } \\
\text { (ADH) type } 1\end{array}$ & 601198 & CASR & CaSR activation & \multirow[t]{2}{*}{$\begin{array}{l}\text { Carpopedal spasms, } \\
\text { tetany, paraesthesia, } \\
\text { seizures, } \\
\text { abdominal pain }\end{array}$} & \multirow[t]{2}{*}{$\begin{array}{l}\text { Hypocalcemia with low or normal PTH, } \\
\text { hypercalciuria, } \\
\text { nephrocalcinosis/nephrolithiasis }\end{array}$} \\
\hline ADH type 2 & 615361 & GNA11 & $\mathrm{G}_{11}$ & & \\
\hline
\end{tabular}




\begin{tabular}{|l|l|l|l|l|l|l|}
\hline $\begin{array}{l}\text { Uromodulin } \\
\text { synthesis }\end{array}$ & $\begin{array}{l}\text { Hyperuricemic } \\
\text { nephropathy, } \\
\text { familial juvenile } \\
1\end{array}$ & 162000 & UMOD & Uromodulin & $\begin{array}{l}\text { Early gout, enuresis, } \\
\text { polyuria }\end{array}$ & $\begin{array}{l}\text { Hyperuricaemia, low urinary levels of } \\
\text { uromodulin, progressive decrease of } \\
\text { GFR }\end{array}$ \\
\hline
\end{tabular}


Table 2. Characteristics of patients with MAGED2 mutations*

\begin{tabular}{|c|c|c|c|c|c|}
\hline Clinical data & $\begin{array}{c}\text { Normal values } \\
\text { (when } \\
\text { applicable) } \\
\end{array}$ & $\begin{array}{l}\text { Laghmani et al. } \\
\qquad(n=15)\end{array}$ & $\begin{array}{l}\text { Legrand et al. } \\
\qquad(n=17)\end{array}$ & $\begin{array}{l}\text { Meyer et al. } \\
\quad(n=1)\end{array}$ & $\begin{array}{l}\text { Arthuis et al. } \\
\qquad(n=1)\end{array}$ \\
\hline Sex & & $15 \mathrm{M}$ & $15 \mathrm{M} / 2 \mathrm{~F}$ & $M$ & $M$ \\
\hline $\begin{array}{l}\text { Onset of } \\
\text { polyhydramnios } \\
\text { (weeks of gestation) }\end{array}$ & & $19(19-20)^{5}$ & $23(18-27)^{2}$ & 21 & 19 \\
\hline $\begin{array}{l}\text { Amniotic fluid index } \\
\text { (cm) }\end{array}$ & $<24$ & $51(36-98)^{8}$ & $42(41-43)^{9}$ & 49 & 50 \\
\hline Bartter index & & NA & $0.73(0.36-1.00)^{4}$ & NA & 0.8 \\
\hline $\begin{array}{l}\text { Number of } \\
\text { amnioreductions }\end{array}$ & & NA & $2(1-11)$ & 5 & 5 \\
\hline $\begin{array}{l}\text { Gestational age at } \\
\text { delivery (weeks) }\end{array}$ & 40 & $28(22-34)$ & $29.5(26-33)$ & 29 & 36 \\
\hline $\begin{array}{l}\text { Weight at birth } \\
\text { (percentile) }\end{array}$ & $10-90$ & NA & $94(53-99)$ & NA & 97 \\
\hline $\begin{array}{l}\text { Height at birth } \\
\text { (percentile) }\end{array}$ & $10-90$ & NA & $94(85-98)^{2}$ & NA & NA \\
\hline Diuresis $(\mathrm{ml} / \mathrm{kg} / \mathrm{h})$ & $1-3$ & NA & $15(3-78)^{1}$ & 20 & No polyuria \\
\hline $\begin{array}{l}\text { Placenta weight to } \\
\text { birth weight ratio } \\
\text { according to weeks of } \\
\text { gestation (percentile) }\end{array}$ & & NA & $\begin{array}{c}N=9 \\
45(27-75)\end{array}$ & NA & NA \\
\hline $\begin{array}{l}\text { Nephrocalcinosis at } \\
\text { diagnosis }\end{array}$ & & $6 / 10$ & $1 / 10$ & No & No \\
\hline $\begin{array}{l}\text { Duration of polyuria } \\
\text { (weeks) }\end{array}$ & & $\begin{array}{c}\mathrm{N}=8 \\
4.5(0.5-6)\end{array}$ & NA & 8 & - \\
\hline $\begin{array}{l}\text { Extrarenal } \\
\text { manifestations }\end{array}$ & & NA & $\begin{array}{c}\text { Frontal bone cyst-pyloric } \\
\text { stenosis ( } 1 \text { case) } \\
\text { High BP. Interauricular } \\
\text { communication and left } \\
\text { ventricle hypertrophy ( } 1 \text { case) } \\
\text { Marfanoid appearance, }\end{array}$ & NA & $\begin{array}{c}\text { Right aortic arch, retro-oesophageal } \\
\text { left subclavian } \\
\text { artery and moderate pulmonary } \\
\text { stenosis }\end{array}$ \\
\hline
\end{tabular}


arachnodactyly, and

mitral insufficiency (1 case)

Acrodermatitis enteropathica

zinc deficiency type (1 case)

Dysmorphic facies (3 cases)

Thrombocytopenia (1 case)

Hydrocephalus and Chiari

malformation (1 case)

Deafness at 2 yr (1 case) Angioma (2 cases)

\begin{tabular}{|c|c|c|c|c|c|}
\hline $\begin{array}{l}\text { Duration of mineral } \\
\text { supplementation } \\
\text { (months) }\end{array}$ & & $\begin{array}{c}N=8 \\
6(1-36)\end{array}$ & $\begin{array}{c}N=7 \\
11(2-18)\end{array}$ & 1 & 1.3 \\
\hline $\begin{array}{l}\text { Duration of } \\
\text { indomethacin } \\
\text { treatment (years) }\end{array}$ & & $\begin{array}{c}N=6 \\
2(1-9)\end{array}$ & $\begin{array}{c}N=6 \\
0.6(0.05-1.5)\end{array}$ & No treatment & No treatment \\
\hline \multicolumn{6}{|l|}{ Blood Data } \\
\hline Sodium (mmol/L) & $134-146$ & $128(123-136)^{6}$ & $136(123-146)^{2}$ & 133 & Normal \\
\hline Chloride (mmol/L) & $97-110$ & $94(84-100)^{6}$ & $104(92-123)^{3}$ & NA & NA \\
\hline Potassium (mmol/L) & $4-6.5$ & $2.9(2.8-3.3)^{6}$ & $4.1(2.4-7.1)^{3}$ & 2.5 & NA \\
\hline Bicarbonate (mmol/L) & $22-29$ & $28(24-38)^{9}$ & $22(12-34)^{4}$ & NA & NA \\
\hline Renin (ng/ml/h) & $4-23$ & $69(11-320)^{9}$ & - & 69.22 & NA \\
\hline Renin (pg/ml) & & & $1520(140-8320)^{12}$ & - & - \\
\hline Aldosterone (ng/dl) & $25-213$ & $\begin{array}{c}1735(107- \\
4260)^{9}\end{array}$ & $170(53-1610)^{10}$ & 325 & NA \\
\hline Urine data & & & & & - \\
\hline $\begin{array}{l}\text { Calcium/creatinine } \\
\text { ratio }(\mathrm{mmol} / \mathrm{mmol})\end{array}$ & $<2.2$ & $14(8-40)^{7}$ & $4(2.3-16)$ & NA & NA \\
\hline $\mathrm{PGE}_{2}\left(\mathrm{ng} / \mathrm{hr} / 1.73 \mathrm{~m}^{2}\right)$ & $4-27$ & $85(8.4-243)^{10}$ & NA & - & NA \\
\hline $\mathrm{PGE}_{2}(\mathrm{ng} / 24 \mathrm{~h})$ & $<8$ & - & NA & 16 & - \\
\hline
\end{tabular}

* Bartter type 3 patients with antenatal phenotype. Values are expressed as medians and min-max range. Superscript values correspond to the number of

missing data points. 
Table 3. Summary of main characteristics of patients with HELIX syndrome

\begin{tabular}{|c|c|c|c|c|c|}
\hline \multicolumn{2}{|l|}{ Publication } & Bongers et al. & Hadj-Rabia et al. & Klar et al. & Meyers et al. \\
\hline \multicolumn{2}{|l|}{ Origin } & Dutch & North Africa & Pakistan & Ecuador \\
\hline \multicolumn{2}{|l|}{ Patients/Families } & $13 / 2$ & $6 / 2$ & $13 / 2$ & $1 / 1$ \\
\hline \multicolumn{2}{|l|}{ Sex } & $1 \mathrm{M} / 1 \mathrm{~F}$ & $3 \mathrm{M} / 3 \mathrm{~F}$ & $6 \mathrm{M} / 7 \mathrm{~F}$ & $M$ \\
\hline \multicolumn{2}{|l|}{$\begin{array}{l}\text { presentations } \\
\text { (years) }\end{array}$} & $21 / 15$ & 4.5- 21 & $27-47$ & 12 \\
\hline \multicolumn{2}{|l|}{ Genotype } & $\begin{array}{l}\text { Compound } \\
\text { heterozygous }\end{array}$ & Homozygous & Homozygous & Homozygous \\
\hline \multicolumn{2}{|l|}{ Hypohidrosis } & Yes $2 / 2$ & Yes 6/6 & Yes 13/13 & Yes $1 / 1$ \\
\hline \multirow{7}{*}{$\begin{array}{l}\text { Electrolyte } \\
\text { abnormalities* }\end{array}$} & \multicolumn{5}{|l|}{ Blood } \\
\hline & Magnesium & $1 \mathrm{H} / 1 \mathrm{~N}$ & $5 \mathrm{H} 1 \mathrm{~N}$ & $5 / 6 \mathrm{H} 1 / 6 \mathrm{~N}$ & $\mathrm{H}$ \\
\hline & Calcium & upper $\mathrm{N}$ & $1 \mathrm{H} 5 \mathrm{~N}$ & $2 / 2 \mathrm{~N}$ & NA \\
\hline & Potassium & L & $4 \mathrm{~L} 2 \mathrm{~N}$ & $6 / 6 \mathrm{~N}$ & L \\
\hline & Bicarbonate & $\mathrm{H}$ & $1 \mathrm{H} 5 \mathrm{~N}$ & $2 / 2 \mathrm{~N}$ & \\
\hline & Renin & NA & $5 \mathrm{H} 1 \mathrm{~N}$ & NA & L \\
\hline & $\begin{array}{l}\text { Urinary } \\
\text { Calcium }\end{array}$ & $\mathrm{L}$ & $\begin{array}{l}\mathrm{L} \mathrm{mg/kg/d} \\
0.59(0.16-1.69)\end{array}$ & $\begin{array}{l}5 / 6 \mathrm{~L} \mathrm{mmol} / \mathrm{L} \\
0.3(01-0.8)\end{array}$ & \\
\hline $\begin{array}{l}\text { Lachrymal } \\
\text { dysfunction }\end{array}$ & & Yes $1 / 2$ & Yes & Yes 13/13 & Yes \\
\hline Ichtyosis & & Yes & Yes & No & No \\
\hline Xerostomia & & Yes & Yes & Yes 13/13 & Yes \\
\hline eGFR $<60$ & & $1 / 2$ & $1 / 6$ & $3 / 13$ & 1 \\
\hline Polyuria & & $1 / 2$ & Yes & & Yes \\
\hline
\end{tabular}

* N: normal; H: high; L: low; NA: not available. 
Figure Legends

Figure 1: Organization of the TAL and the nephron. A. The TAL of short-looped nephrons is located in outer medulla and cortex (left), whereas the TAL of longlooped nephrons is located in the inner medulla and inner stripe of the outer medulla (right).

Figure 2. Diagram of thick ascending limb. Shown are the top cells from the cortex and of the outer stripe of the outer medulla (OSOM) and on the bottom cells of the inner stripe of the outer medulla (ISOM). Vertical arrows indicate the tubular flow direction. Transepithelial $\mathrm{Na}^{+}$reabsorption is electroneutral via NKCC2 (inhibited by furosemide). The rate-limiting step for the function of NKCC2 is the availability of $\mathrm{K}^{+}$. It is recycled via the potassium channel Kir1.1 leading to hyperpolarization of the apical membrane. $\mathrm{Na}^{+}$exits the cell on the basolateral side via the $\mathrm{Na}^{+}-\mathrm{K}^{+}-\mathrm{ATPase}$, and $\mathrm{Cl}^{-}$exits via the chloride channels $\mathrm{ClC}-\mathrm{Ka}$ and $\mathrm{ClC}-\mathrm{Kb}$, which depolarize the basolateral membrane. This process generates a lumen-positive transepithelial potential difference that drives paracellular reabsorption of cations. In the cortex and OSOM, divalent cations, $\mathrm{Ca}^{+2}$ and $\mathrm{Mg}^{+2}$, are reabsorbed via the claudin-16/19 complex. In the ISOM, paracellular reabsorption of $\mathrm{Na}^{+}$occurs via claudin-10b. In the cortex and OSOM, claudins-16/19 and claudin-10b are not expressed in the same tight junctions. As the concentration of $\mathrm{NaCl}$ of tubular fluid arriving into the cortical TAL is lower, a paracellular backflow of $\mathrm{Na}^{+}$via the tight junctions expressing claudin-10b occurs (right panel), which contributes to maintenance of the lumenpositive transepithelial potential. The calcium-sensing receptor CaSR is expressed in the basolateral membrane. Its activation induces the expression of claudin-14. The proteins defective in diseases described in this review are indicated by boxes (see Table 1).

Figure 3. A. Predicted topology of claudin-10b, showing the mutations detected to date. Extracellular loop 1 (ECL1); extracellular loop 2 (ECL2). B. Role of the claudin10b. In the secretory part of sweat glands and the acinar cells of salivary and lacrimal glands, the cooperative action of the basolateral NKCC1 cotransporter, the $\mathrm{K}$ channel, Na/K ATPase, and the luminal CFTR results in $\mathrm{Cl}^{-}$secretion into the lumen 
and $\mathrm{Na}^{+}$and $\mathrm{K}^{+}$exit from basolateral side. The secretion of $\mathrm{Cl}^{-}$drives $\mathrm{Na}^{+}$transport via the paracellular pathway due to the function of claudin-10b as channel and transcellular water transport via aquaporin-5 (AQP5). An abrogation of the claudin10b-mediated $\mathrm{Na}^{+}$transport results in dysfunction of sweat, saliva, and tear glands. 


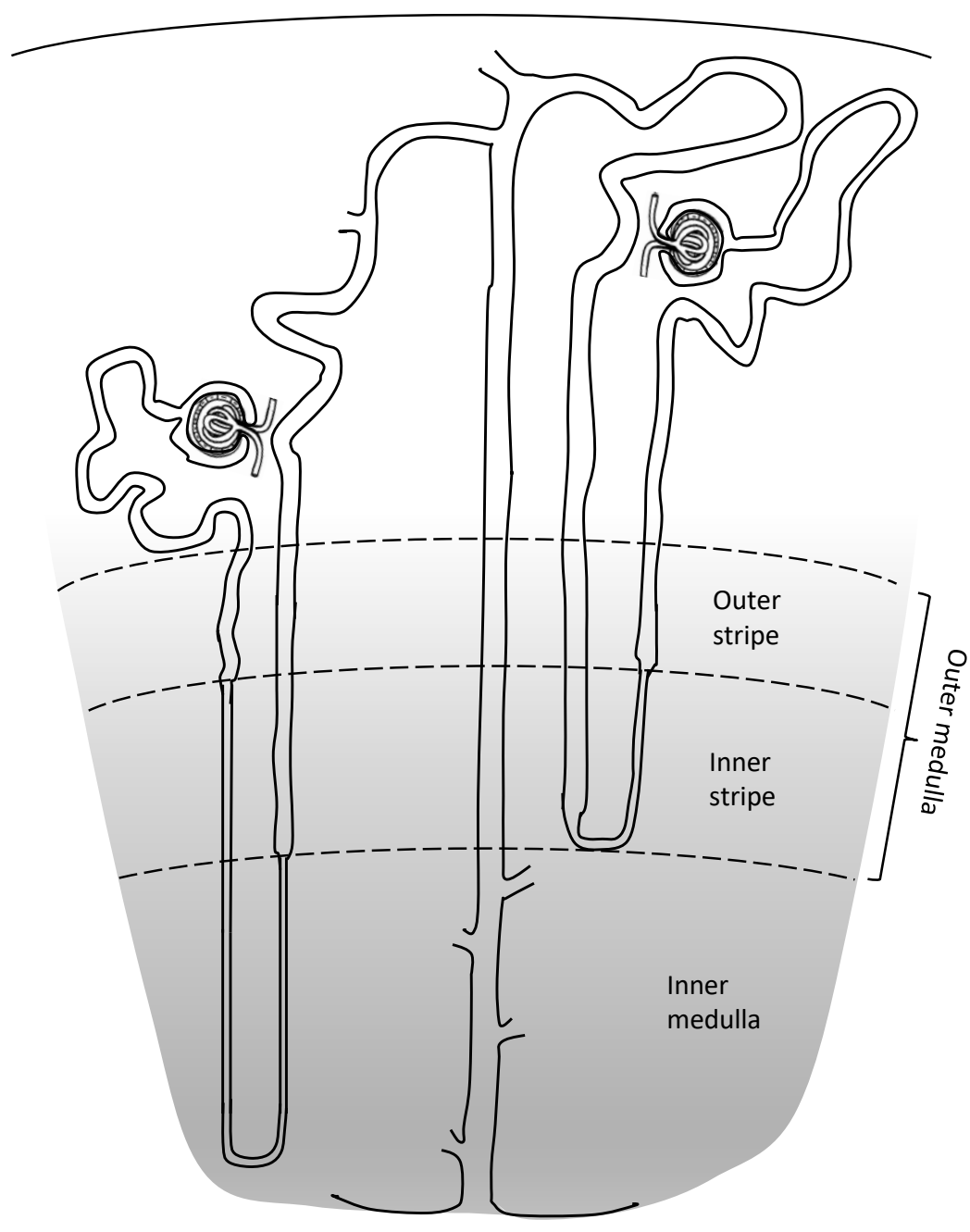

Figure 1 
Furosemide

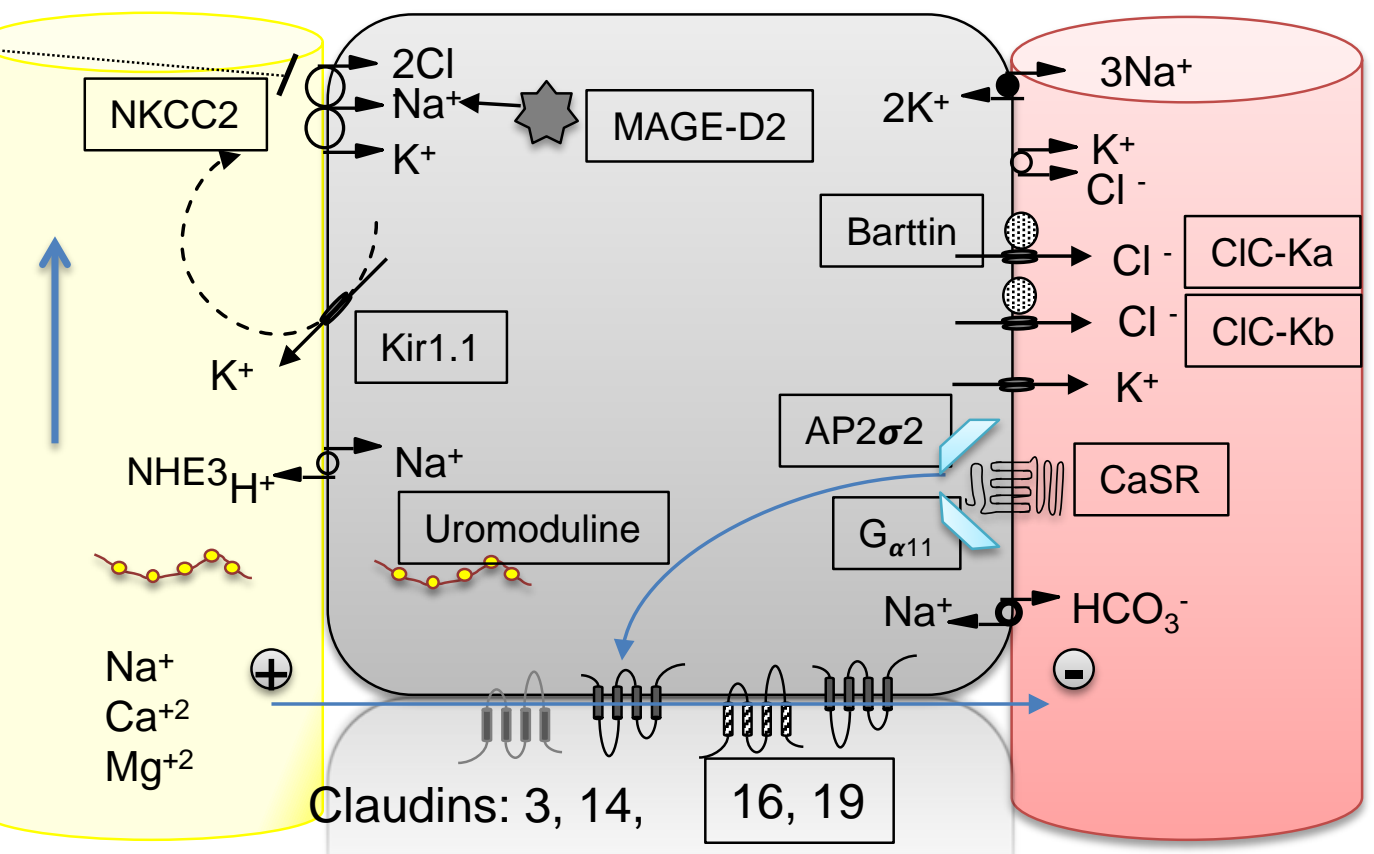

\section{Cortex and OSOM}

$\oplus$

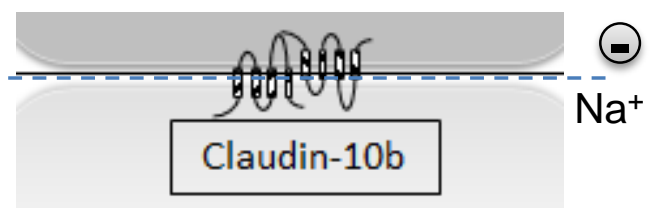

Furosemide

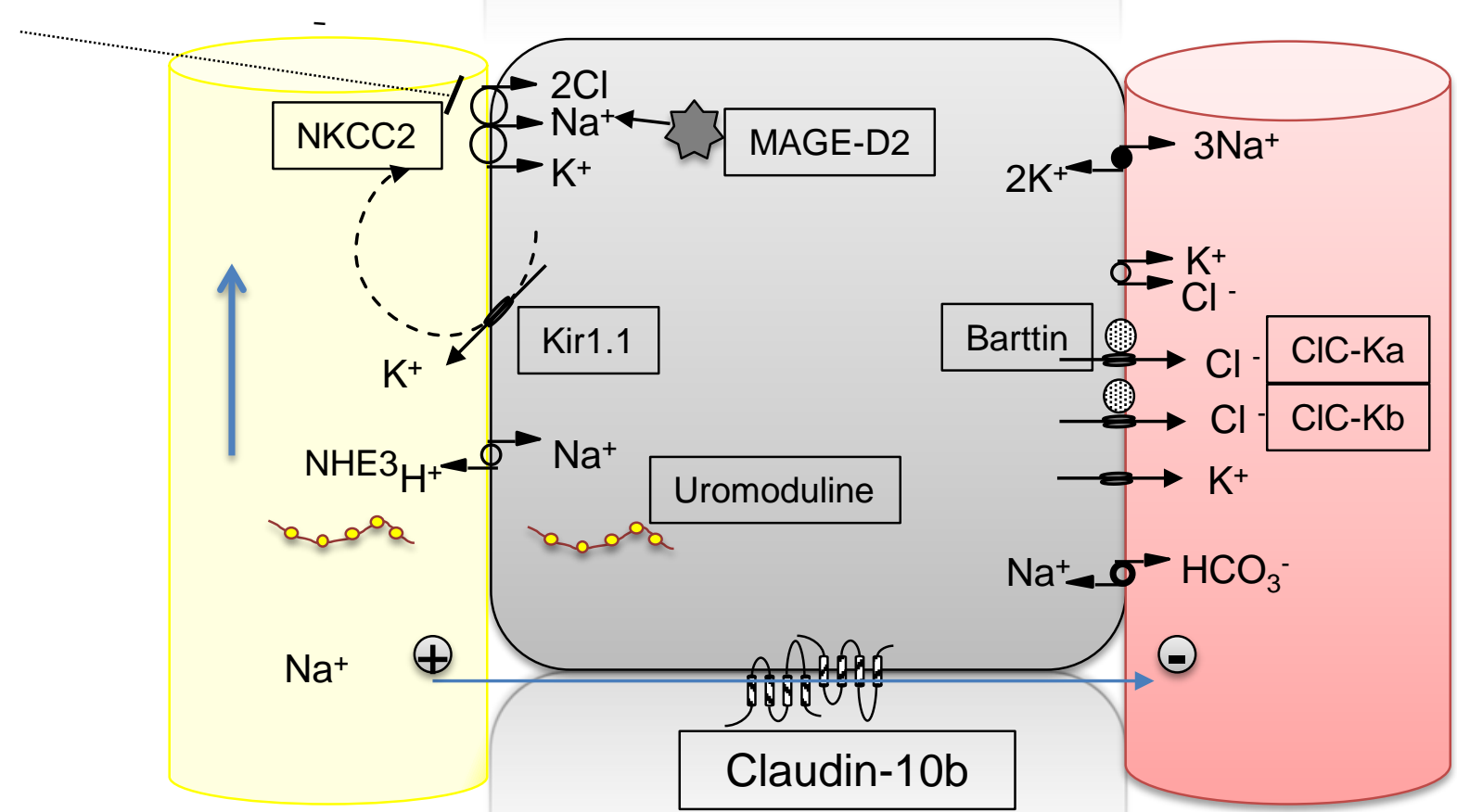

ISOM

Figure 2 
Lumen

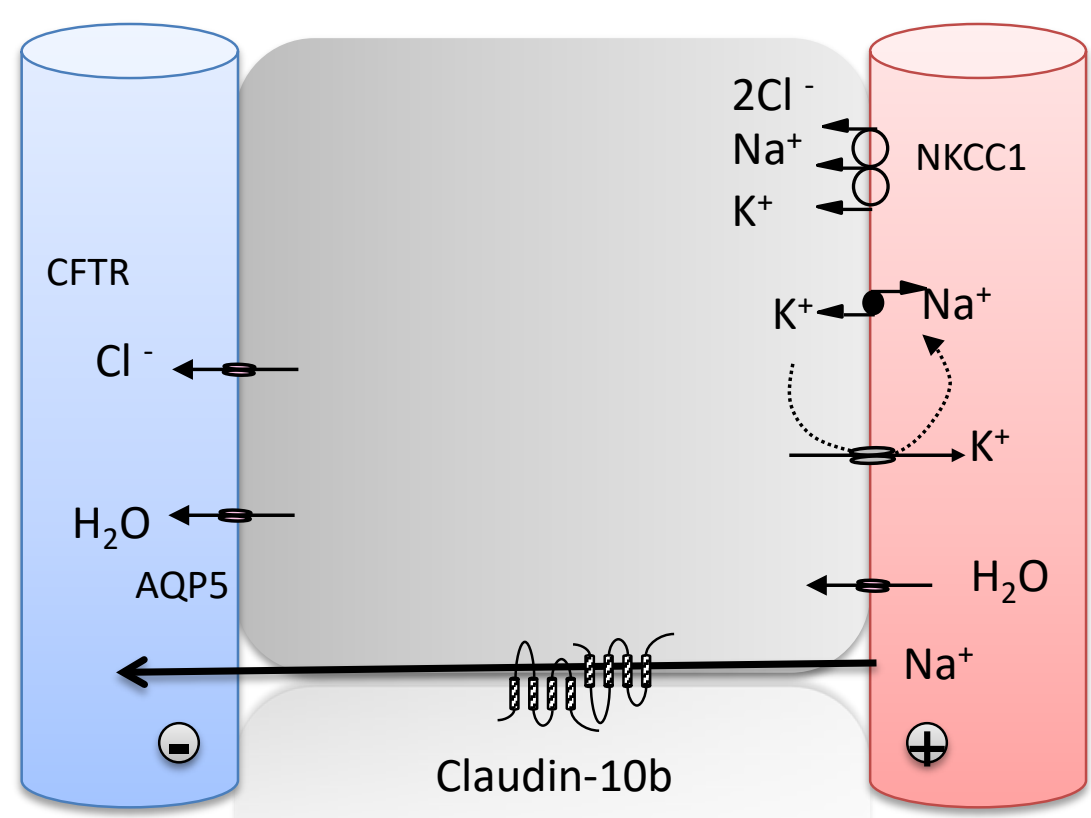

